\title{
Child Sexual Abuse Prevention Program: Reference to the Indonesian Government
}

\author{
Ghaisani Ikramina Aiffah ${ }^{1)}$, Wandera Ahmad Religia ${ }^{2)}$ \\ 1 Depertment of Health Promotion and Behavior Science, Faculty of Public Health, Universitas \\ Airlangga, Surabaya, Indonesia \\ 2 National Population and Family Planning Agency, East Java, Indonesia \\ Email: ghaisani.ikramina.aiffah-2017@fkm.unair.ac.id
}

\begin{abstract}
Background: Child Sexual Abuse (CSA) was a global problem widespread in many countries. Komisi Perlindungan Anak Indonesia or Indonesian Children Protection Commission (KPAl) recorded as many as 1.880 children become victims of sexual abuse such as rape, fornication, sodomy and paedophilia. The Government of Indonesia become made become efforts both national and international scale, but there is no effective and applicable program that has been implemented. Objective: The purpose of this article was to analyse the programs had been implemented to prevent sexual violence against children. Method: This article was a literature study by examining 38 articles related to the program against child abuse. The researcher was looking for reference sources from the Science Direct, Sage pub and Google Scholar online become. The keywords used were Child Sex Abuse Prevention Program, Parenting Program, Parent Training, Parent Intervention, Maltreatment, Violence, and Violence Prevention. Result: In children, programs that had been implemented include C-SAPE; IGEL; Train the trainer; BST; A program for minorities in Australia; Cool and Safe. For parents, the programs that had been applied include ACT-RSK; Triple-P; RETHINK; The Incredible Years Parents, Teachers, and Children Training Series; PACE; The Making Choices and Strong Families; The African Migrant Parenting; Strengthening Families; 123 Magic; PDEP and FAST. Conclusion: The sexual violence prevention program for children that can be implemented by the Indonesian government was using teaching methods based on school curricula that can be delivered by teachers. For parent, the program that could be implemented by the Indonesian government was using positive parenting methods that focus on preventing sexual violence against children and delivered by expert facilitators. To reach children and families with different cultural backgrounds, the Indonesian government could adapt sexual violence prevention programs for the Australian minorities and The African Migrant Parenting.
\end{abstract}

Keyword: child sexual abuse, prevention program

\section{INTRODUCTION}

A child is someone under 18 (eighteen) years of age, including a child in the womb (Perubahan Atas UndangUndang Nomor 23 Tahun 2002 Tentang Perlindungan Anak, 2014). Children have the rights to be recognised in international law since 1924 when the Declaration on the Rights of International Children is first adopted by the League of Nations. The next Instruments of the human rights, from the United Nations, such as the Universal Declaration of Human Rights 1948, and regional instruments such as the American
Declaration of Human Rights and obligations made in the same year, acknowledging more generally the human right to be free from violence, abuse, and exploitation (Convention on the Rights of the Child, 1989; Czerwinski et al., 2018).

Since 2011-2016, the Indonesian Children Protection Commission (KPAl) recorded as many as 809 children that focus victims of online sexual crimes and 1,880 children become victims of sexual abuse such as rape, fornication, sodomy and paedophilia (Komisi Perlindungan Anak Indonesia, 2016). The Ministry of Social Affairs recorded 1.956 children victims of sexual abuse in 2016 and 
increased to 2.117 children in 2017 (Permani, 2018).

The Indonesian Government has made efforts to prevent both national and international scales. On a national scale the effort was made by ratifying the Convention on the Rights of the children on September 2, 1990; Established Law No. 23 of 2002 and it is updated to Act No. 35, 2014 about child protection; Established the Ministry of Women Empowerment and Child Protection, establishing the women's Empowerment office, child protection, population control and disaster families (DP3AP2KB); In cooperation with both central and regional police in child protection; with immigration in the event of deportation of foreigners who proved to be the perpetrator of paedophilia and with the child protection institutions KPAl, Forum and Children's Council. Internationally, Indonesia also collaborates with NCBINTERPOL in international/transnational crime prevention in Indonesia (Melati et al., 2015; Septia, 2016; Utami, 2018).

It can be concluded that there have been efforts to prevent sexual abuse in children conducted by the Indonesian Government; however, KPAI commissioner chairman Putu Elvina states that an effective and applicable program as part of efforts to prevent harassment was not available (Dedi Hendrian, 2018). Therefore, the researcher is interested in collecting what become ever been applied as a preventative effort against sexual abuse in children.

\section{METHOD}

First step was search references from the Science Direct, Sage pub and Google Scholar. The keywords used were Child Sex Abuse Prevention Program, Parenting Program, Parent Training, Parent Intervention, Maltreatment, Violence, and Violence Prevention. The total articles were 17,697 from 2010 until 2019, yet those were only identified and unexplored. After that, the researcer explored just 38 articles related to the prevention program of sexual abuse in children.

Of the 38 articles found, there were 17 sexual violence prevention programs consisting of 6 sexual violence prevention programs for chikdren and 9 sexual prevention programs for parents. Of the
17 programs found, 4 programs were inisiated by the goverment and 13 programs were initiated by Non Government Organizations (NGOs).

Of the 38 articles found, they were categorized into two groups, namely: child prevention programs and parental prevention programmes. Those programs were implemented in Europe, America, Australia, Africa and Asia. The results of this literature study were expected to be a picture for the Indonesian government regarding efforts to prevent sexual violence against children.

\section{RESULTS AND DISCUSSION}

In many countries, studies on policymaking and sexual violence prevention program for children have been conducted. The researcher divides the results of literature studies into two categories namely, children's preventive programs. A sexual violence prevention program for children is a program that focuses on providing interventions for children so that the child is able to protect themselves. A program for preventing sexual violence for parents is a program that focuses on providing intervention to parents so that parents can prevent their children becoming victims of sexual violence.

Child preventive Program, all the preventive efforts made to the child are based on the child as the primary victim who will have a complex public health problem for life after becoming a victim of sexual violence (Müller, Röder and Fingerle, 2014; Czerwinski et al., 2018; Bustamante et al., 2019). Table 1 shows that there are several programs to prevent sexual violence against children which have been implemented in several countries. The programs include C-SAPE, IGEL, Train the trainer, BST, The program for Australian minorities, Cool and Safe.

C-SAPE (The Child Sexual Abuse Prevention Education) is a child sexual abuse prevention program by incorporating sexual education in an elementary school education curriculum. This program aims to teach children about sexual harassment and provided skills to children to avoid sexual harassment (National Sexual Violence Resource Center, 2011). The benefits of the C-SAPE program include: increasing children's knowledge about sexual harassment and 
self-protection, increasing children's skills in reporting and asking for help, increasing self-confidence (del Campo Sanchez and Sanchez, 2006; Walsh and Brandon, 2012; Kim and Kang, 2017).

Germany implements the IGEL program. The program aims to increase the strength and ability of children to protect themselves from sexual abuse. After implementing, the child could protect themselves from sexual harassment (Czerwinski et al., 2018).

Early sexual education in elementary school children has been implemented in several countries. Hawaii undertakes development by including a school based train the trainer program. The program aims to increase children's awareness of situations that are at risk for sexual harassment (Keeping Children Safe Coalition, 2011). The program is effectively implemented and could increase children's knowledge about body boundaries, appropriate and inappropriate touches (Baker et al., 2012; Barron and Topping, 2013).

The Body Safe Training (BST) program is a child sexual abuse prevention program developed by Dr Wurtele in 1986 and updated in 2007. The program purposes to help children recognize potential abusive situations, teach children to say no, fight the harassers, and report their experience (Lucy Faithfull Foundation, 2014). Output of this program is that children could protect themselves from sexual harassment by recognizing situations that have the potential to be harassing, being able to say no, being able to fight off the offender and being able to report sexual harassment experienced (Zhang et al., 2014).

Preventive efforts with school based early sexual education in children are a method that is very commonly done. Several countries that have implemented this prevention program do not consider cultural factors in the design of program designs. In Australia, the implementation of this program has made the minorities there increasingly marginalized and racism is created. Cultural factors also need to be considered in the design and evaluation of prevention programs for school based children (Sawrikar and Katz, 2018).

Technological advances can also be utilized as an innovation to health programs. An inovation program called "Cool and Safe" was created as an effort to prevent web-based child sexual abuse targeting children of elementary school age. This program aims to prevent child sexual abuse by providing knowledge about safe behavior, appropriate touches and inapproproate touches. The program has been tested and results show that the program is worth applying and has no significant anxiety side effects (Müller, Röder and Fingerle, 2014).

Table 1 shows that there are 6 sexual violence prevention programs for children. Preventing children from becoming victims of sexual violence is the core objective of them. From those programs, 3 programs were carried out in 2 sessions, 1 program was carried out in 3 sessions and 2 programs are not explained in the literature. The topics presented are divided into 2 categories. The first category is about basic education including what sexual harassment is, the types of touch and how to behave safely and what are the places at risk. The second category is more related to how to avoid sexual harassment, how to protect yourself from the perpetrators (dare to say no, dare to fight and dare to report about sexual abuse experience) and how to increase sensitivity to unsafe conditions.

Of the 6 sexual violence prevention programs for children found, it can be concluded that the target of the program is children between 3-13 years of age or in other words it focuses on pre-school to elementary school age children. In Indonesia, cases of sexual violence against children recorded by the Ministry of Social Affairs in 2017 reached 2.117 cases (Permani, 2018). The age range of victims of sexual violence in Indonesia is between 0-16 years old (VOA, 2019).

From the 6 programs found, it can be concluded that the program presenters differ depending on the program. The program is a curriculum based program, the school teachers, counseling teachers and religious teachers can be presenters. The program is not curriculum based program, then the presenter is an expert trainer (Rahmaniah, 2014). 
Table 1. Syntesis Matrix result of Child Prevention Program

\begin{tabular}{|c|c|c|c|c|c|c|c|}
\hline Program & Reference & Inisiator & $\begin{array}{l}\text { Country/ } \\
\text { Regional }\end{array}$ & Objectives & Method & Result & Benefit/Barier \\
\hline C-SAPE & $\begin{array}{l}\text { (National } \\
\text { Sexual } \\
\text { Violence } \\
\text { Resource } \\
\text { Center, } \\
\text { 2011), } \\
\text { (Walsh and } \\
\text { Brandon, } \\
\text { 2012); (Kim } \\
\text { and Kang, } \\
\text { 2017) }\end{array}$ & Goverment & USA & $\begin{array}{l}\text { 1. Teach children how } \\
\text { to recognize sexual } \\
\text { harrasment } \\
\text { 2. Provide skills for } \\
\text { children to avoid } \\
\text { sexual harassment }\end{array}$ & $\begin{array}{l}\text { 1. Implemetation: } 1-2 \\
\text { sessions or more } \\
\text { 2. Presenters: class } \\
\text { teachers, counseling } \\
\text { teachers, religious } \\
\text { teachers } \\
\text { 3. Topic: adjusted to the } \\
\text { target } \\
\text { 4. Target: children aged } \\
\text { 3-12 years }\end{array}$ & $\begin{array}{l}\text { Parents feel } \\
\text { compatible with } \\
\text { the topic being } \\
\text { taught and can } \\
\text { improve self } \\
\text { protective } \\
\text { behavior in } \\
\text { children }\end{array}$ & $\begin{array}{l}\text { Benefit: } \\
\text { 1. Increase knowledge } \\
\text { of children about } \\
\text { sexual abuse } \\
\text { 2. Increase knowledge } \\
\text { and self protection } \\
\text { skills in children } \\
\text { 3. Improve the child's } \\
\text { skills in reporting } \\
\text { and asking for help } \\
\text { 4. Increase children's } \\
\text { confidence } \\
\text { Barier: } \\
\text { 1. Parents are less } \\
\text { involved } \\
\text { 2. Lack of school } \\
\text { partnership }\end{array}$ \\
\hline IGEL & $\begin{array}{l}\text { (Czerwinski } \\
\text { et al., 2018) }\end{array}$ & Goverment & Germany & $\begin{array}{l}\text { 1. Increase the } \\
\text { strength and ability }\end{array}$ & $\begin{array}{l}\text { 1. Implementation: } 3 \\
\text { sessions } \\
\text { senters: }-^{\text {a }} \\
\text { jic: body boundary } \\
1 \text { type of touch } \\
\text { get: } 3^{\text {rd }} \text { grader of } \\
\text { elementary school }\end{array}$ & $\begin{array}{l}\text { Children can } \\
\text { protect themselves } \\
\text { from sexual abuse }\end{array}$ & $\begin{array}{l}\text { Benefit: } \\
\text { 1. Increase the child's } \\
\text { knowledge of body } \\
\text { boundaries, } \\
\text { appropriate and } \\
\text { inappropriate } \\
\text { touches } \\
\text { Barier: } \\
\text {-a }\end{array}$ \\
\hline $\begin{array}{l}\text { Train the } \\
\text { trainer }\end{array}$ & $\begin{array}{l}\text { (Baker et } \\
\text { al., 2012), } \\
\text { (Barron and } \\
\text { Topping, } \\
\text { 2013), } \\
\text { (Keeping } \\
\text { Children } \\
\text { Safe }\end{array}$ & $\begin{array}{l}\text { Non } \\
\text { Goverment }\end{array}$ & $\begin{array}{l}\text { Europe and } \\
\text { Africa }\end{array}$ & $\begin{array}{l}\text { 1. Increase the child's } \\
\text { awareness about } \\
\text { situations at risk for } \\
\text { sexual harassment }\end{array}$ & $\begin{array}{l}\text { 1. Implementation: } 2 \\
\text { sessions } \\
\text { 2. Presenters: trainers } \\
\text { 3. Topic: risky pepople } \\
\text { and places, grooming } \\
\text { behavior, appropriate } \\
\text { touch and sexual } \\
\text { language }\end{array}$ & $\begin{array}{l}\text { The program is } \\
\text { suitable to be } \\
\text { applied in social } \\
\text { work practices }\end{array}$ & $\begin{array}{l}\text { Benefit: } \\
\text { 1. Increase children's } \\
\text { knowledge about } \\
\text { body boundaries, } \\
\text { appropriate and } \\
\text { inappropriate } \\
\text { touches } \\
\text { Barier: }\end{array}$ \\
\hline
\end{tabular}

(C)2020. Jurnal Promkes: The Indonesian Journal of Health Promotion and Health 
242 Jurnal Promkes: The Indonesian Journal of Health Promotion and Health Education

Vol. 8 No. 2, September 2020, 238-252 doi: 10.20473/jpk.V8.12.2020.238-252

\begin{tabular}{|c|c|c|c|c|c|c|c|}
\hline Program & Reference & Inisiator & $\begin{array}{l}\text { Country/ } \\
\text { Regional }\end{array}$ & Objectives & Method & Result & Benefit/Barier \\
\hline & $\begin{array}{l}\text { Coalition, } \\
\text { 2011) }\end{array}$ & & & & $\begin{array}{l}\text { 4. Target: school staff } \\
\text { and children aged 6-13 } \\
\text { years old }\end{array}$ & & $\begin{array}{l}\text { 1. Culture } \\
\text { 2. Distance } \\
\text { 3. Lack of information } \\
\text { 4. Infrastructure } \\
\text { 5. Policy }\end{array}$ \\
\hline BST & $\begin{array}{l}\text { (Lucy } \\
\text { Faithfull } \\
\text { Foundation, } \\
\text { 2014), } \\
\text { (Zhang et } \\
\text { al., 2014) }\end{array}$ & $\begin{array}{l}\text { Non } \\
\text { Goverment }\end{array}$ & USA & $\begin{array}{l}\text { 1. Help the children } \\
\text { recognize potential } \\
\text { abusive situations } \\
\text { 2. Teach children to } \\
\text { say no } \\
\text { 3. Teach children to } \\
\text { fight the offender } \\
\text { 4. Teach children to } \\
\text { report sexual abuse } \\
\text { experience }\end{array}$ & $\begin{array}{l}\text { 1. Implementation: } 2 \\
\text { sessions } \\
\text { 2. Presenters: - a } \\
\text { 3. Topic: session } 1 \text { about } \\
\text { public safety } \\
\text { (fire,pedestrian, gun, } \\
\text { home alone), session } 2 \\
\text { about body safety } \\
\text { (body safety skills, } \\
\text { recognizing against and } \\
\text { reporting } \\
\text { inappropriate touches) } \\
\text { 4. Target: children aged } \\
\text { 3-8 years old }\end{array}$ & $\begin{array}{l}\text { Children can } \\
\text { protect themselves } \\
\text { from sexual abuse }\end{array}$ & $\begin{array}{l}\text { Benefit: } \\
\text { 1. Children can } \\
\text { reconize potential } \\
\text { abusive situations } \\
\text { 2. Children can say no } \\
\text { 3. Children can fight } \\
\text { the offenders } \\
\text { 4. Children can report } \\
\text { sexual abused } \\
\text { experience } \\
\text { Barier: } \\
-a^{-}\end{array}$ \\
\hline $\begin{array}{l}\text { Cool and } \\
\text { Safe }\end{array}$ & $\begin{array}{l}\text { (Müller, } \\
\text { Röder and } \\
\text { Fingerle, } \\
\text { 2014) }\end{array}$ & $\begin{array}{l}\text { Non } \\
\text { Goverment }\end{array}$ & $\begin{array}{l}\text { Europe and } \\
\text { USA }\end{array}$ & $\begin{array}{l}\text { 1. Prevent child sexual } \\
\text { abuse by providing } \\
\text { knowledge about } \\
\text { the type of touch } \\
\text { and how to behave } \\
\text { safety }\end{array}$ & $\begin{array}{l}\text { 1. Implementation: }-^{\mathrm{a}} \\
\text { 2. Presenters: }-^{\mathrm{a}} \\
\text { 3. Topic: type of touch } \\
\text { and how to behave } \\
\text { safety } \\
\text { 4. Target: elementary } \\
\text { school children }\end{array}$ & $\begin{array}{l}\text { Program are } \\
\text { effective in } \\
\text { teaching children } \\
\text { about safe } \\
\text { behavior }\end{array}$ & $\begin{array}{l}\text { Benefit: } \\
\text { 1. Increase knowledge } \\
\text { and skills about } \\
\text { safe behavior } \\
\text { Barier: } \\
- \text { a }^{-}\end{array}$ \\
\hline
\end{tabular}

(C)2020. Jurnal Promkes: The Indonesian Journal of Health Promotion and Health 
Of all the available programs, it has been proven to be effective and able to increase the target's knowledge and skills on what and how to protect themselves from sexual harassment. Barriers to implementing the program include less involved parents, less partnered schools, cultural factors, distance, information, infrastucture and policies. Indonesia has the similar conditions. Child sexual abuse that occur in Indonesia is the result from lack of attention from parents to children because parents are busy (VOA, 2019). Cultural background makes it difficult to teach sexuality material to children because it is one of the factors that makes it easy for perpetrators of sexual abuse from abroad to enter Indonesia (Irawan, 2016).

Indonesia has not implemented an effective and applicable program related to the prevention of sexual violence against children (Dedi Hendrian, 2018). The Ministry of Women's Empowerment and Child Protection implements the Three Ends program. The program aims to end violence against women and children, end human trafficking and end economic inequality (Kementerian Pemberdayaan Perempuan dan Perlindungan Anak, 2016). End violence against women and children were carried out by providing information on the rights of women and children that reached the entire Indonesian community, functioning village-level institutuions, functioning of the women's and child protection task force in the regions and ensuring massive support from stakeholders (Kementerian Pemberdayaan Perempuan dan Perlindungan Anak, 2016). Efforts to prevent sexual violence against children are briefly alluded to in the Three Ends program, but it has not specifically focused on preventing sexual violence against children. Efforts made by Indonesia are making policies in the form of laws and conducting partnerships with various organizations both government and private (Septia, 2016).

Efforts to prevent sexual violence againts children are not done only by the government. A non governmental organization, ECPAT Indonesia implemented a sexual violence againts children prevention with the Smart School Online Module for Children "Eksploitasi Seksual Anak di Ranah Online". The topics presented by expert facilitators were what was sexual exploitation of children in the online realm, who was vulnerable to being the perpetrators and victims of sexual exploitation of children in the online realm, why sexual exploitation of children in the online realm could occur and what could children do to prevent sexual exploitation (ECPAT Indonesia, 2018).

Prevention programs of sexual abuse in children are often only focused on children. Development Program to the parent domain is also required. Knowledge obtained by children from the school cannot be applied optimally. The parental role is required as an amplifier; in this case, it is a preventive effort of sexual abuse in children (Rudolph and Zimmer-Gembeck, 2018; Rudolph et al., 2018).

Table 2 shows that parents can be involved in efforts to prevent violence against children. Parents can provide supervision and monitoring, provide protection to children, and help increasing children's knowledge about self protection. Parental involvement need as an efforts to prevents sexual violence against children. It can be advocated to the government to be included in the program to prevent sexual violence against children (Letourneau et al., 2017; Rudolph and Zimmer-Gembeck, 2018; Rudolph et al., 2018; Jin, Chen and Yu, 2019). Programs to prevent sexual violence against children for parents include ACT-RSK; Triple-P; The Incredible Years Parents, Teachers, and Children Training Series; PACE; The Making Choices and Strong Families; The African Migrant Parenting; Strengthening Families; 123 Magic; PDEP; FAST.

Americans adopt the ACT-RSK (ACT-Raising Safe Kids) program as an effort to reduce early childhood violence. This program aims to reduce the number of child abuse (Knox and Burkhart, 2011, 2014; Knox, Burkhart and Hunter, 2011).

Triple-P program is very effective. Significant decrease in children's conflict, an increase in closeness and positive relationships between parents and children and an increase in parental competence in childcare are side effects of this program (Breitkreuz et al., 2011; Morawska et al., 2011; Sumargi, Sofronoff and Morawska, 2014; Ashori et al., 2015). 
The Incredible Years Parents, Teachers, and Children Training Series is a reinforcement programfor parents, teachers, children, and families. The program aims to improve the social, emotional and academic competence of parents and teachers to prevent children from developing behavioral problems (Webster-Stratton, 2011). The effectiveness of this program has been tested and the results is, fewer students have behavioral problems when they are taught by parents and teachers who have received program training. This happens because there is an increase in the skills of parents and teachers in childcare and classroom management (Furlong and McGilloway, 2012; Wager, Wager and Wilson, 2015).

PACE (Parenting our Children to Excellence) is a parenting training program designed to improve parents' coping and self efficacy skills in childcare (Audience, 2017). This program has been tested on 610 parents in Indianapolis, United States. The results show that the PACE program could significantly improve harmonious relations between parents and children, especially for families who have the potential to abuse children (Begle and Dumas, 2011).

The Making Choices and Strong Families is a program designed to strengthen families by increasing parenting skills and developing emotional management in children. This program is effective in promoting harmonious relations between parents and children (Conner and Fraser, 2011; Fraser et al., 2014). The African Migrant Parenting is a childcare program implemented by the Spectrum Migrant Resource Center to ensure new immigrants and refugees in Australia could maximize their potential to care for children, strengthen their role so as to produce positive childcare. As a results, Immigrants and refugees in Australia can maximally educate their children even though their cultural backgrounds differ from where they came from. After getting educated, parents have different perspectives on physical submission and access to food for their children (Leone, 2014).

Strengthening Families is an internationally recognized family empowerment program that is proven effective in improving children's mental health. The results of the effectiveness study show that this program is able to reduce anger, make the child's parents' relationship better and provide understanding to parents about child care (Riesch et al., 2012; Burn et al., 2019). 123 Magic is a parental strengthening program that focuses on emotional control. The purpose of this program is to improve parenting skills in positives parenting. This program is effectively implemented because parents could take care of children posititvely and the environtment around the child became harmonious (Phelan, 2016).

Positive Discipline in Everyday Parenting (PDEP) is a parenting approach program that educates and guides children in good behavior. The program was carried out in 4 sessions and the topic was about parenting. Benefits of the program include: parents no longer use physical punishment, it increases parental self efficacy and reduces conflict between parents and children (Durrant et al., 2014; Durrant, 2017).

Family And School Together (FAST) is a program created by the United Nations Office on Drugs and Crime (UNODC). FAST is a multi-family intervention aiming to improve parental empowerment so that it could build a good relationship with the child (Maalouf and Campello, 2014). This program has been implemented in several countries, such as Turkmenistan, Kyrgyzstan, Guatemala, Nicaragua, Albania, Serbia, Montenegro, Macedonia, Bosnia Herzegovia and Brazil. The result of implementing the program is that parents become active in activities that involved their children (McDonald and Sayger, 1998; Maalouf and Campello, 2014).

Table 2 shows that there are 11 sexual violence prevention programs for parents. The core objective of the various programs is educating children to behave well. In achieveing these core goal, each program takes a similar approach, namely by teaching about good parenting. Parenting method is done by managing emotions, increasing the coping mechanisms and self eficacy of parents, and doing parental empowerment. Children who have a bad childhood background (mistreated and become victims of sexual violence) potential to become perpetrators of sexual violence in the future. The low quality of self from perpetrators of sexual violence against 
children shows that the family which is expected to provide the basis for the development of the child's personality does not fuction properly, including the function of family control, and the family environtment does not work well (Teja, 2016).

Of the 11 sexual violence prevention programs for parent found, the length of implementation of the program depends on the topic provided and the target audience. If the target is multisectoral, then the topic is taught a lot and the teaching time is longer. Of all available programs, the subject matter will be taught by expert trainers. This is the same as the presenters in the program of sexual violence prevention in children that are not based on school curricula. The goal of the whole program is parents. Based on sexual violence against children data in Indonesia, most of the perpetrators come from families with violent parenting. The existence of conflict in the family causes the perpetrator to not be able to correctly identify the roles of men and women. This is what causes the perpetrators to grow into a paedophile (Handayani, 2012).

All programs have been proven effective because they are able to reduce the number of violence in children, parents are able to manage emotions so that the relationship between parents and children becomes more harmonious. Barries to the program are location, time, cost, and goverment commitment. This obstacle is almost similar with the obstacle in sexual violence prevention for children. Indonesia is a country with diverse cultural background and an archipelago (Lestari, 2015). Government commitment is one of the many barriers to policy implementation in Indonesia (VOA, 2019).

Since 2016, Indonesia has implemented a positive parenting program, The purpose of this program was to build a warm relationship between children and parents and stimulated child develompment. The material taught were the stage of child development, effective communication and positive discipline (Kemendikbud, 2016). Compared to prevention programs for child sexual violence for parents that have been carried out abroad, this positive parenting program was not specific yet. But in this implementation, there were some material regarding reproductive health and early detection of deviant behavior (Kemendikbud, 2016).

A non governmental organization, ECPAT Indonesia implemented a violence against children prevention with the Smart School Online Module for Family and Teacher "Eksploitasi Seksual Anak di Ranah Online". The topic presented by expert facilitators were a general understanding of the sexual exploitation of children in the online realm and what could be done to prevent the exploitation of children in the online realm (ECPAT Indonesia, 2018). 
246 Jurnal Promkes: The Indonesian Journal of Health Promotion and Health Education

Vol. 8 No. 2, September 2020, 238-252 doi: 10.20473/jpk. V8.I2.2020.238-252

Table 2. Syntesis Matrix result of Parental Prevention Program

\begin{tabular}{|c|c|c|c|c|c|c|c|c|}
\hline Program & Reference & Inisiator & $\begin{array}{l}\text { Country/ } \\
\text { Regional }\end{array}$ & & Objectives & Method & Result & Benefit/Barier \\
\hline ACT-RSK & $\begin{array}{l}\text { (Knox and } \\
\text { Burkhart, } \\
\text { 2011), (Knox, } \\
\text { Burkhart and } \\
\text { Hunter, 2011), } \\
\text { (Knox and } \\
\text { Burkhart, 2014) }\end{array}$ & $\begin{array}{l}\text { Non } \\
\text { Goverment }\end{array}$ & USA & 1. & $\begin{array}{l}\text { Reduce the } \\
\text { number of } \\
\text { violence in } \\
\text { children }\end{array}$ & $\begin{array}{l}\text { 1. Implementation: } 8 \text { sessions } \\
\text { 2. Presenters: trainers } \\
\text { 3. Topic: children's behavior, } \\
\text { violence against children, } \\
\text { emotional management, } \\
\text { problem solving, discipline, } \\
\text { the influence of media on } \\
\text { children, practicum } \\
\text { 4. Target: parents and } \\
\text { caregivers }\end{array}$ & $\begin{array}{l}\text { Effectively reduce the } \\
\text { level of bullying in } \\
\text { children }\end{array}$ & $\begin{array}{l}\text { Benefit: } \\
\text { 1. Parents' } \\
\text { knowledge, } \\
\text { behavior and } \\
\text { beliefs about } \\
\text { violence } \\
\text { prevention and } \\
\text { parenting methods } \\
\text { are increasing } \\
\text { Barier: } \\
\text { - }^{-}\end{array}$ \\
\hline Triple-P & $\begin{array}{l}\text { (Sanders, } \\
\text { 2008), } \\
\text { (Breitkreuz et } \\
\text { al., 2011), } \\
\text { (Morawska et } \\
\text { al., 2011), } \\
\text { (Sumargi, } \\
\text { Sofronoff and } \\
\text { Morawska, } \\
\text { 2014), (Ashori } \\
\text { et al., 2015) }\end{array}$ & $\begin{array}{l}\text { Non } \\
\text { Goverment }\end{array}$ & Australia & 1. & $\begin{array}{l}\text { Increase } \\
\text { parents' } \\
\text { knowledge, } \\
\text { skills and } \\
\text { confidence in } \\
\text { maintaining } \\
\text { chiildren's } \\
\text { behavior }\end{array}$ & $\begin{array}{l}\text { 1. Implementation: } 5 \text { sessions } \\
\text { 2. Presenters: trainers } \\
\text { 3. Topic: mass media, primary } \\
\text { health care services, } \\
\text { religious organizations, } \\
\text { political systems and } \\
\text { childcare and school } \\
\text { systems } \\
\text { 4. Target: parents }\end{array}$ & $\begin{array}{l}\text { There is a significant } \\
\text { decrease in children's } \\
\text { conflict, increase } \\
\text { closeness between } \\
\text { parents and children, } \\
\text { increase parental } \\
\text { competence in } \\
\text { chilcare }\end{array}$ & $\begin{array}{l}\text { Benefit: } \\
\text { 1. Prevent problems } \\
\text { with behavior, } \\
\text { emotions and poor } \\
\text { development in } \\
\text { children } \\
\text { Barier: } \\
\text { 1. Location } \\
\text { 2. Time } \\
\text { 3. Costs } \\
\text { 4. Work commitment }\end{array}$ \\
\hline $\begin{array}{l}\text { The } \\
\text { Incredible } \\
\text { Years } \\
\text { Parents, } \\
\text { Teachers, } \\
\text { and } \\
\text { Children } \\
\text { Training } \\
\text { Series. }\end{array}$ & $\begin{array}{l}\text { (Webster- } \\
\text { Stratton, 2011), } \\
\text { (Furlong and } \\
\text { McGilloway, } \\
\text { 2012), (Wager, } \\
\text { Wager and } \\
\text { Wilson, 2015) }\end{array}$ & $\begin{array}{l}\text { Non } \\
\text { Goverment }\end{array}$ & USA & 1. & $\begin{array}{l}\text { Increase the } \\
\text { social, } \\
\text { emotional and } \\
\text { academic } \\
\text { competence of } \\
\text { parents and } \\
\text { teachers to } \\
\text { prevent children } \\
\text { from developing } \\
\text { behavioral } \\
\text { problems }\end{array}$ & $\begin{array}{l}\text { 1. Implementation: baby } \\
\text { program ( } 9-12 \text { sessions), } \\
\text { toddler program (12 } \\
\text { sessions), preschool } \\
\text { program (18-20 sessions), } \\
\text { school age program (12-16 } \\
\text { sessions) } \\
\text { 2. Presenters: trainers } \\
\text { 3. Topic: depends on the type } \\
\text { of program } \\
\text { 4. Target: parents. Children } \\
\text { and families }\end{array}$ & $\begin{array}{l}\text { Fewer students have } \\
\text { behavioral problems } \\
\text { when they are taught } \\
\text { by parents and } \\
\text { teachers who have } \\
\text { received program } \\
\text { training }\end{array}$ & $\begin{array}{l}\text { Benefit: } \\
\text { 1. Increase parenting } \\
\text { skills by managing } \\
\text { anger } \\
\text { 2. Increase teacher } \\
\text { skills in classroom } \\
\text { management } \\
\text { Barier: } \\
\text {-a }\end{array}$ \\
\hline PACE & $\begin{array}{l}\text { (Begle and } \\
\text { Dumas, 2011), } \\
\text { (Audience, } \\
\text { 2017) }\end{array}$ & $\begin{array}{l}\text { Non } \\
\text { Goverment }\end{array}$ & USA & 1. & $\begin{array}{l}\text { Improve } \\
\text { parents' coping } \\
\text { skills and self- } \\
\text { effficacy in } \\
\text { parenting }\end{array}$ & $\begin{array}{l}\text { 1. Implementation: } 1 \text { session } \\
\text { for } 1 \text { year } \\
\text { 2. Presenters: trainers } \\
\text { 3. Material: bringing out the } \\
\text { best in children, }\end{array}$ & $\begin{array}{l}\text { The involvement of } \\
\text { PACE can significantly } \\
\text { increase the } \\
\text { harmonious } \\
\text { relationship between }\end{array}$ & $\begin{array}{l}\text { Benefit: } \\
\text { 1. Improve childcare } \\
\text { skills of parents } \\
\text { who are at risk of } \\
\text { child abuse }\end{array}$ \\
\hline
\end{tabular}

C2020. Jurnal Promkes: The Indonesian Journal of Health Promotion and Health

PROMKES Education. Open Access under CC BY-NC-SA License.

Received: 29-01-2020, Accepted: 28-08-2020, Published Online:28-09-2020 


\begin{tabular}{|c|c|c|c|c|c|c|c|}
\hline Program & Reference & Inisiator & $\begin{array}{l}\text { Country/ } \\
\text { Regional }\end{array}$ & Objectives & Method & Result & Benefit/Barier \\
\hline & & & & & $\begin{array}{l}\text { recognizing children's } \\
\text { strengths, reducing child } \\
\text { problem behaviors, coping } \\
\text { and self efficacy for } \\
\text { parents } \\
\text { 4. Target: parents of children } \\
\text { aged 3-6 years }\end{array}$ & parents and children & $\begin{array}{l}\text { Barier: } \\
\text {-a }\end{array}$ \\
\hline $\begin{array}{l}\text { The Making } \\
\text { Choices } \\
\text { and Strong } \\
\text { Families }\end{array}$ & $\begin{array}{l}\text { (Conner and } \\
\text { Fraser, 2011), } \\
\text { (Fraser et al., } \\
\text { 2014) }\end{array}$ & $\begin{array}{l}\text { Non } \\
\text { Goverment }\end{array}$ & USA & $\begin{array}{l}\text { 1. Enhance } \\
\text { parenting skills } \\
\text { and developing } \\
\text { emotional } \\
\text { management in } \\
\text { children }\end{array}$ & $\begin{array}{l}\text { 1. Implementation: } 1 \text { session } \\
\text { 2. Presenters: trainers } \\
\text { 3. Topic: emotional } \\
\text { management } \\
\text { 4. Target: parents }\end{array}$ & $\begin{array}{l}\text { Effective in promoting } \\
\text { harmonious relations } \\
\text { between parents and } \\
\text { children }\end{array}$ & $\begin{array}{l}\text { Benefit: } \\
\text { 1. Enhance } \\
\text { harmonious } \\
\text { relationship } \\
\text { between parents } \\
\text { and children } \\
\text { Barier: } \\
\text { _a }\end{array}$ \\
\hline $\begin{array}{l}\text { The African } \\
\text { Migrant } \\
\text { Parenting }\end{array}$ & (Leone, 2014) & Goverment & Australia & $\begin{array}{l}\text { 1. Ensure new } \\
\text { immigrants and } \\
\text { refugees } \\
\text { (parents) in } \\
\text { Australia can } \\
\text { maximize their } \\
\text { potential in } \\
\text { parenting }\end{array}$ & $\begin{array}{l}\text { 1. Implementation: } 8 \text { sessions } \\
\text { 2. Presenters: trainers } \\
\text { 3. Topic: understanding } \\
\text { children's needs. } \\
\text { Children's confidence, } \\
\text { communication, education } \\
\text { for children, legal issues, } \\
\text { stress management, } \\
\text { childcare in different } \\
\text { cultural backgrounds } \\
\text { 4arget: parent from sub- } \\
\text { Sadaran African } \\
\text { backgrounds }\end{array}$ & $\begin{array}{l}\text { Immigrants and } \\
\text { refugees in Australia } \\
\text { can maximize } \\
\text { educating their } \\
\text { children even though } \\
\text { their cultural } \\
\text { backgrounds are } \\
\text { different from where } \\
\text { they came from }\end{array}$ & $\begin{array}{l}\text { Benefit: } \\
\text { 1. Change the } \\
\text { perspective of } \\
\text { parents regarding } \\
\text { the application of } \\
\text { physical } \\
\text { punishment to } \\
\text { children and } \\
\text { restrictions on } \\
\text { access to food } \\
\text { Barier: } \\
\text {-a }\end{array}$ \\
\hline $\begin{array}{l}\text { Strengtheni } \\
\text { ng Families }\end{array}$ & $\begin{array}{l}\text { (Riesch et al., } \\
\text { 2012), (Burn et } \\
\text { al., 2019) }\end{array}$ & $\begin{array}{l}\text { Non } \\
\text { Goverment }\end{array}$ & USA & $\begin{array}{l}\text { 1. Improve } \\
\text { parenting skills } \\
\text { and improve } \\
\text { children's } \\
\text { mental health }\end{array}$ & $\begin{array}{l}\text { 1. Implementation: } 3 \text { sessions } \\
\text { 2. Presenter: trainers } \\
\text { 3. Topic: childcare and } \\
\text { children's mental health }\end{array}$ & $\begin{array}{l}\text { Parents are able to } \\
\text { manage their stress }\end{array}$ & $\begin{array}{l}\text { Benefit: } \\
\text { 1. Reduce the level } \\
\text { of anger in parents } \\
\text { 2. Improve parents' } \\
\text { understanding of } \\
\text { parenting } \\
\text { 3. Children's } \\
\text { behavior get } \\
\text { better } \\
\text { Barier: } \\
\text { _a }\end{array}$ \\
\hline
\end{tabular}

(C)2020. Jurnal Promkes: The Indonesian Journal of Health Promotion and Health

JURNAL Education. Open Access under CC BY-NC-SA License.

Received: 29-01-2020, Accepted: 28-08-2020, Published Online:28-09-2020 
248 Jurnal Promkes: The Indonesian Journal of Health Promotion and Health Education Vol. 8 No. 2, September 2020, 238-252 doi: 10.20473/jpk.V8.I2.2020.238-252

\begin{tabular}{|c|c|c|c|c|c|c|c|}
\hline Program & Reference & Inisiator & $\begin{array}{l}\text { Country/ } \\
\text { Regional }\end{array}$ & Objectives & Method & Result & Benefit/Barier \\
\hline & & Goverment & & $\begin{array}{l}\text { parenting skills } \\
\text { in positive } \\
\text { parenting }\end{array}$ & $\begin{array}{l}\text { 2. Presenters: }-^{\mathrm{a}} \\
\text { 3. Topic: parents are the } \\
\text { caregivers of children and } \\
\text { parental duties } \\
\text { 4. Target: parents }\end{array}$ & $\begin{array}{l}\text { parental skills in } \\
\text { positive parenting }\end{array}$ & $\begin{array}{l}\text { 1. Parents can } \\
\text { positively care for } \\
\text { children } \\
\text { 2. Children do not } \\
\text { behave deviant } \\
\text { 3. The environment } \\
\text { around the } \\
\text { children becomes } \\
\text { harmonious } \\
\text { Barier: } \\
\text {-a }\end{array}$ \\
\hline PDEP & $\begin{array}{l}\text { (Durrant et al., } \\
\text { 2014), } \\
\text { (Durrant, 2017) }\end{array}$ & $\begin{array}{l}\text { Non } \\
\text { Goverment }\end{array}$ & $\begin{array}{l}\text { Southeas } \\
\text { t Asia }\end{array}$ & $\begin{array}{l}\text { 1. Educate and } \\
\text { guide children } \\
\text { to behave well }\end{array}$ & $\begin{array}{l}\text { 1. Implementation: } 4 \text { sessions } \\
\text { 2. Presenters: trainers } \\
\text { 3. Topic: parenting } \\
\text { 4. Target: parents }\end{array}$ & $\begin{array}{l}\text { PDEP can improve } \\
\text { parenting skills in } \\
\text { educating children }\end{array}$ & $\begin{array}{l}\text { Benefit: } \\
\text { 1. Physical } \\
\text { punishment is no } \\
\text { longer used } \\
\text { 2. Parents' self } \\
\text { efficacy increases } \\
\text { 3. Conflict between } \\
\text { parents and } \\
\text { children is reduced } \\
\text { Barier: } \\
-\mathrm{a}\end{array}$ \\
\hline FAST & $\begin{array}{l}\text { (Maalouf and } \\
\text { Campello, } \\
\text { 2014) }\end{array}$ & $\begin{array}{l}\text { Non } \\
\text { Goverment }\end{array}$ & $\begin{array}{l}\text { Turkmeni } \\
\text { stan, } \\
\text { Kyrgyzsta } \\
\text { n, } \\
\text { Guatema } \\
\text { la, } \\
\text { Nicaragu } \\
\text { a, } \\
\text { Albania, } \\
\text { Serbia, } \\
\text { Montene } \\
\text { gro, } \\
\text { Macedoni } \\
\text { a, } \\
\text { Bosnia, } \\
\text { Herzegov } \\
\text { ia and } \\
\text { Brazil }\end{array}$ & $\begin{array}{l}\text { 1. Increase } \\
\text { parental } \\
\text { empowerment } \\
\text { so the } \\
\text { relationship } \\
\text { between } \\
\text { parents and } \\
\text { children is more } \\
\text { harmonious }\end{array}$ & $\begin{array}{l}\text { 1. Implementation: } 8-12 \\
\text { weeks } \\
\text { 2. Presenters: trainers } \\
\text { 3. Topic: alcohol, } \\
\text { antisocial/aggressive } \\
\text { behavior, illegal drugs, } \\
\text { social and emotional } \\
\text { competence } \\
\text { 4. Target: individuals, } \\
\text { families, peers, schools, } \\
\text { communities }\end{array}$ & $\begin{array}{l}\text { Parents become active } \\
\text { in activities that } \\
\text { involve their children }\end{array}$ & $\begin{array}{l}\text { Benefit: } \\
\text { 1. Communication } \\
\text { between parent } \\
\text { and child increases } \\
\text { 2. Parents are } \\
\text { involved in } \\
\text { activities in the } \\
\text { school and } \\
\text { community } \\
\text { Barier: } \\
\text { 1. Schools pay less } \\
\text { attention to } \\
\text { anything other } \\
\text { than academic } \\
\text { activities }\end{array}$ \\
\hline
\end{tabular}

(C)2020. Jurnal Promkes: The Indonesian Journal of Health Promotion and Health 


\section{CONCLUSION}

There are already several sexual violence prevention programs for children and parents. Indonesian government can implement the same program to reduce the number of cases of child sexual abuse that continues to increase. Program barriers that occur in countries that implement programs to prevent sexual violence against children can be used as a reference source for the Indonesian goverment in developing stategic program that are approriate to the characteristics of the country. The type of program that is suitable to be carried out in Indonesia is a combination of various programs that have been carried out. For programs to prevent sexual violence for children, it can be done by using school curriculumbased teaching methode with classroom teacher, counseling teachers and religious teacher as a presenter. Using modules as a guide like what ECPAT Indonesia has done can also support the learning process. For programs to prevent sexual violence for parents, it can be done as a positive parenting program that has been implemented in Indonesia since 2016.

\section{REFERENCE}

Ashori, M. et al. (2015) 'Group positive parenting program (Triple-P) and the relationships of mother-child with intellectual disability', Practice in Clinical Psychology, 3(1), pp. 31-38.

Audience, T. (2017) 'Parenting Our Children to Excellence (PACE)', (July).

Baker, C. K. et al. (2012) 'Increasing Knowledge of Sexual Abuse', Research on Social Work Practice, 23(2), pp. 167-178. doi: 10.1177/1049731512468796.

Barron, I. G. and Topping, K. J. (2013) 'Survivor Experience of a Child Sexual Abuse Prevention Program: A Pilot Study', Journal of Interpersonal Violence, 28(14), pp. 2797-2812. doi: $10.1177 / 0886260513488690$.

Begle, A. M. and Dumas, J. E. (2011) 'Child and parental outcomes following involvement in a preventive intervention: Efficacy of the PACE program', Journal of Primary Prevention, 32(2), pp. 67-81. doi: 10.1007/s10935-010-0232-6.

Breitkreuz, R. et al. (2011) 'Integrating
Triple P into Existing Family Support Services: A Case Study on Program Implementation Integrating Triple $\mathrm{P}$ into Existing Family Support Services : A Case Study on Program Implementation', (December 2016). doi: $10.1007 / \mathrm{s} 11121-011-0233-6$.

Burn, M. et al. (2019) 'Parents' perceptions of changes in family functioning after participation in a strengthening families intervention: A qualitative analysis', Children and Youth Services Review. Elsevier, 100(March), pp. 428-436. doi: 10.1016/j.childyouth.2019.03.028.

Bustamante, G. et al. (2019) "“I have the right to feel safe": Evaluation of a school-based child sexual abuse prevention program in Ecuador', Child Abuse and Neglect. Elsevier, 91(November 2018), pp. 31-40. doi: 10.1016/j.chiabu.2019.02.009.

del Campo Sanchez, A. and Sanchez, F. L. (2006) 'Evaluation of school-based child sexual abuse prevention program', Psicothema, 18(1), pp. 1-8.

Conner, N. W. and Fraser, M. W. (2011) 'Preschool social-emotional skills training: A controlled pilot test of the making choices and strong families programs', Research on Social Work Practice, 21(6), pp. 699-711. doi: $10.1177 / 1049731511408115$.

Convention on the Rights of the Child (1989) 'Convention on the Rights of the Child'.

Czerwinski, F. et al. (2018) 'Effectiveness of a school-based intervention to prevent child sexual abuseEvaluation of the German IGEL program', Child Abuse and Neglect. Elsevier, 86(May), pp. 109-122. doi: 10.1016/j.chiabu.2018.08.023.

Dedi Hendrian (2018) Marak Pedofilia, Upaya Perlindungan Anak Dinilai Jalan di Tempat. Available at: https://www.kpai.go.id/berita/marak -pedofilia-upaya-perlindungan-anakdinilai-jalan-di-tempat.

Durrant, J. E. et al. (2014) 'Preventing Punitive Violence: Preliminary Data on the Positive Discipline in Everyday Parenting (PDEP) Program', Canadian Journal of Community Mental Health, 33(2), pp. 109-125. doi: 10.7870/cjcmh-2014-018.

Durrant, J. E. (2017) 'Positive Discipline in Everyday Parenting Facilitator' $s$ One D ay Refresher Workshop Positive 
Discipline in Everyday Parenting Facilitator' s One Day Refresher Workshop'.

ECPAT Indonesia (2018) Modul Smart School Online untuk Anak 'Eksploitasi Seksual Anak di Ranah Online'. Jakarta: ECPAT Indonesia. Available at:

https://ecpatindonesia.org/publikasimedia/modul-smart-school-onlineuntuk-anak-eksploitasi-seksual-anakdi-ranah-online/.

Fraser, M. W. et al. (2014) 'The Making Choices Program Author(s): Mark W. Fraser, Aaron M. Thompson, Steven H. Day and Rebecca J. Macy Source: The Elementary School Journal, (-Not available-), p. 000 Published by':

Furlong, M. and McGilloway, S. (2012) 'The Incredible Years Parenting program in Ireland: A qualitative analysis of the experience of disadvantaged parents', Clinical Child Psychology and Psychiatry, 17(4), pp. 616-630. doi: $10.1177 / 1359104511426406$

Handayani, P. K. (2012) 'Mengungkap Profil Pelaku Pedofilia Melalui Tes Kepribadian', pp. 1-33.

Irawan, N. F. R. (2016) 'Efektivitas ECPAT Indonesia dalam Menangani Kejahatan Child Sex Tourism di Indonesia: Studi Kasus Child Sex Tourism di Bali Tahun 2012-2014', Journal of International Relations, 2(3), pp. 64-69.

Jin, Y., Chen, J. and Yu, B. (2019) 'Parental practice of child sexual abuse prevention education in China: Does it have an influence on child's outcome?', Children and Youth Services Review. Elsevier, 96(November 2018), pp. 64-69. doi: 10.1016/j.childyouth.2018.11.029.

Keeping Children Safe Coalition (2011) 'Keeping Children Safe Toolkit: Tool 3 - Training for Child Protection', in Keeping Children Safe: A Toolkit for Child Protection. Keeping Children Safe Coalition. Available at: http://www.keepingchildrensafe.org. uk/toolkit.

Kemendikbud (2016) Seri Pendidikan Orang Tua: Pengasuhan Positif. 1st edn. Edited by A. M. Solihin and Y. T. Prabowo. Jakarta: Kementerian Pendidikan dan Kebudayaan.

Kementerian Pemberdayaan Perempuan dan Perlindungan Anak (2016) Program prioritas kementerian pemberdayaan perempuan dan perlindungan anak. Available at: https://www.kemenpppa.go.id/index .php/page/view/4.

Kim, S. J. and Kang, K. A. (2017) 'Effects of the child sexual abuse prevention education (C-SAPE) program on south Korean fifth-grade students' competence in terms of knowledge and self-protective behaviors', Journal of School Nursing, 33(2), pp. 123-132. doi: $10.1177 / 1059840516664182$.

Knox, M. and Burkhart, K. (2011) 'Effects of the ACT Raising Safe Kids Parenting Program on Children' $s$ Externalizing Problems', 60(October), pp. 491-503. doi: $\quad 10.1111 / \mathrm{j} .1741$ 3729.2011.00662.x.

Knox, M. and Burkhart, K. (2014) 'A multisite study of the ACT Raising Safe Kids program: Predictors of outcomes and attrition', Children and Youth Services Review. Elsevier Ltd, 39, pp. 20-24. doi: 10.1016/j.childyouth.2014.01.006.

Knox, M. S., Burkhart, K. and Hunter, K. E. (2011) 'ACT Against Violence Parents Raising Safe Kids Program: Effects on Maltreatment- Related Parenting Behaviors and Beliefs'. doi: 10.1177/0192513X10370112.

Komisi Perlindungan Anak Indonesia (2016) Data Kasus Anak Pemantauan Media Online - 2016. Available at: https: //bankdata.kpai.go.id/tabulasidata/data-kasus-dari-mediaonline/data-kasus-anak-pemantauanmedia-online-2016.

Leone, S. (2014) 'The impact of a parenting intervention in Australia among migrants and refugees from Liberia , Sierra Leone, Congo , and Burundi: Parenting Program', 9400(January 2017), pp. 71-79. doi: 10.5172/jfs.2011.17.1.71.

Lestari, G. (2015) 'Bhinnekha Tunggal Ika: Khasanah Multikultural', Jurnal Pendidikan Pancasila dan Kewarganegaraan, 1, pp. 31-37.

Letourneau, E. J. et al. (2017) 'Preventing the Onset of Child Sexual Abuse by Targeting Young Adolescents With Universal Prevention Programming', Child Maltreatment, 22(2), pp. 100-111. doi: $10.1177 / 1077559517692439$.

Lucy Faithfull Foundation (2014) Body Safety Training Workbook (BST). 
Maalouf, W. and Campello, G. (2014) 'The influence of family skills programmes on violence indicators: Experience from a multi-site project of the United Nations Office on Drugs and Crime in low and middle income countries', Aggression and Violent Behavior. Elsevier Ltd, 19(6), pp. 616624. doi: 10.1016/j.avb.2014.09.012.

MCDonald and Sayger (1998) Families and Schools Together (FAST) SAMSHHSA Model Programs.

Melati, D. P. et al. (2015) 'Implementasi Penanganan Kasus Kekerasan Terhadap Anak Oleh Komisi Perlindungan', 9(1), pp. 33-48.

Morawska, A. et al. (2011) 'Is the Triple P-Positive Parenting Program Acceptable to Parents from Culturally Diverse Backgrounds?', pp. 614-622. doi: $10.1007 / \mathrm{s} 10826-010-9436-x$.

Müller, A. R., Röder, M. and Fingerle, M. (2014) 'Child sexual abuse prevention goes online: Introducing "cool and Safe" and its effects', Computers and Education, 78, pp. 60-65. doi: 10.1016/j.compedu.2014.04.023.

National Sexual Violence Resource Center (2011) 'Child Sexual Abuse Prevention', pp. 1-16.

Permani, A. W. (2018) 'Data Kemensos Sebut Kasus Kekerasan Seksual Anak Meningkat', Suara Surabaya. Available at:

https: / / www.suarasurabaya.net/kela nakota/2018/Data-Kemensos-SebutKasus-Kekerasan-Seksual-AnakMeningkat/.

Perubahan Atas Undang-Undang Nomor 23 Tahun 2002 Tentang Perlindungan Anak (2014).

Phelan, T. W. (2016) 1-2-3 Magic Effective Discipline for Children 2-12. 6th edn. Sourcebooks.

Rahmaniah, A. N. (2014) 'Identifikasi Kebutuhan Pendidikan Kesehatan Reproduksi Pada Anak Usia Sekolah Prapubertas di Kota Serang Tahun 2014', pp. 1-17.

Riesch, S. K. et al. (2012) 'Strengthening Families Program (10-14): Effects on the Family Environment', 34(3). doi: 10.1177/0193945911399108.Strengthe ning.

Rudolph, J. et al. (2018) 'Child Sexual Abuse Prevention Opportunities: Parenting, Programs, and the Reduction of Risk', Child Maltreatment, 23(1), pp. 96-106. doi:
10.1177/1077559517729479.

Rudolph, J. and Zimmer-Gembeck, M. J. (2018) 'Parents as protectors: A qualitative study of parents' views on child sexual abuse prevention', Child Abuse and Neglect. Elsevier, 85(July), pp. 28-38. doi: 10.1016/j.chiabu.2018.08.016.

Sanders, M. R. (2008) 'Triple P-Positive Parenting Program as a Public Health Approach to Strengthening Parenting', Journal of Family Psychology, 22(4), pp. 506-517. doi: 10.1037/08933200.22.3.506.

Sawrikar, P. and Katz, I. (2018) 'Preventing child sexual abuse (CSA) in ethnic minority communities: A literature review and suggestions for practice in Australia', Children and Youth Services Review. Elsevier, 85(December 2017), pp. 174-186. doi: 10.1016/j.childyouth.2017.12.028.

Septia, M. P. (2016) 'Upaya Indonesia dalam Penanganan Kasus Pedofilia di Pulau Bali', IOSR Journal of Economics and Finance, 3(1), p. 56. doi: https: / / doi.org/10.3929/ethz-b000238666.

Sumargi, A., Sofronoff, K. and Morawska, A. (2014) 'Evaluation of a Brief Format of the Triple P-Positive Parenting Program: A Pilot Study With Indonesian Parents Residing in Australia', 31, pp. 144-158. doi: 10.1017/bec.2014.7.

Teja, M. (2016) 'Kondisi Sosial Ekonomi dan Kekerasan Seksual pada Anak', Majalah Info Singkat Kesejahteraan Sosial, VIII(09).

Utami, P. N. (2018) 'Pencegahan Kekerasan Terhadap Anak dalam Perspektif Hak Atas Rasa Aman Di Nusa Tenggara Barat', Jurnal HAM, 9(1), $\quad$ p. $1 . \quad$ doi: 10.30641/ham.2018.9.1-17.

VOA (2019) Kasus Kekerasan Fisik dan Seksual pada Anak Meningkat di RI. Available

at: https: //www.voaindonesia.com/a/kas us-kekerasan-fisik-dan-seksual-padaanak-meningkat-di-ri/5029008.html.

Wager, N. M., Wager, A. R. and Wilson, C. (2015) 'Circles South East ' s programme for partners of child sex offenders: A preliminary outcome evaluation'. doi: 10.1177/0264550515600541.

Walsh, K. and Brandon, L. (2012) 'Their Children 's First Educators : Parents' 
252 Jurnal Promkes: The Indonesian Journal of Health Promotion and Health Education Vol. 8 No. 2, September 2020, 238-252 doi: 10.20473/jpk.V8.12.2020.238-252

Views About Child Sexual Abuse Prevention Education', pp. 734-746. doi: 10.1007/s10826-011-9526-4.

Webster-Stratton, C. (2011) The incredible years $\circledR^{\circledR}$. Incredible Years, Inc.

Zhang, W. et al. (2014) 'Evaluation of a
Sexual Abuse Prevention Education for Chinese Preschoolers', Research on Social Work Practice, 24(4), pp. 428436. doi: $10.1177 / 1049731513510409$. 